\title{
FLYPAPER EFFECT THEORY DALAM IMPLEMENTASI KEBIJAKAN DESENTRALISASI FISKAL
}

\author{
Suyanto \\ Fakultas Ekonomi Universitas Dr. Soetomo Surabaya \\ Jalan Semolowaru 84 Surabaya Telpon 5924452
}

Diterima 20 Januari 2010/ Disetujui 5 Mei 2010

\begin{abstract}
Fiscal decentralization can be considered as intergovernmental financial assistance within a state. This assistance is commonly called intergovernmental financial transfer that is transfer of fund from a level of government to another level. Generally, the transfer is usually occurred from a higher level of government the lower counterpart of a single state. The research is conducted to prove that Flypaper Effect has occurred in fiscal decentralization policy. The research finds that regional governments use the transfer for increasing their expenditures without raising the tax. The impact which is occurred from correlation of financial transfer by central government toward the income and expenditure of regional governments shows flypaper effect indication in the implementation of fiscal decentralization. In that case, the effect to the increase in regional expenditure is bigger than the effect toward its income. This is showing that transfer of the fund has caused the increase in vertical fiscal imbalance. Transfer of funds encourages the increase in the expenditure of autonomous regions.
\end{abstract}

Keywords: fiscal decentralization, intergovernmental transfer, vertical fiscal imbalance, flypaper effect

\begin{abstract}
Abstrak: Desentralisasi fiskal dapat dipandang sebagai bantuan keuangan antarpemerintah dalam suatu negara. Bantuan keuangan ini sering disebut sebagai transfer keuangan antar pemerintahan, yaitu transfer dana dari satu tingkat pemerintahan ke tingkat pemerintahan yang lain. Kebanyakan transfer dari tingkat pemerintahan yang lebih tinggi ke tingkat pemerintahan yang lebih rendah dalam suatu negara. Penelitian ini dilakukan untuk membuktikan terjadinya fenomena Flypaper Effect dalam kebijakan desentralisasi fiskal. Pemerintah daerah dalam menerima transfer/hibah dipergunakan untuk meningkatkan pengeluarannya tanpa harus meningkatkan pajak daerah. Terjadinya pengaruh dari semestinya dalam hubungan transfer keuangan pemerintah pusat terhadap sisi penerimaan ataupun sisi pengeluaran pemerintah daerah membuktikan adanya gejala flypaper effect dalam pelaksanaan desentralisasi fiskal; yang mana efek peningkatan pada pengeluaran lebih besar dari efek terhadap pendapatan daerah. Hal ini dapat dibuktikan oleh adanya transfer dana perimbangan telah menimbulkan terjadinya ketimpangan fiskal (vertikal fiscal imbalance) menjadi lebih besar. Dana transfer mendorong peningkatan pengeluaran daerah otonom menjadi semakin besar.
\end{abstract}

Kata kunci: desentralisasi fiskal, intergovernmental transfer, ketimpangan fiskal vertikal, flypaper effect

\section{PENDAHULUAN}

Dewasa ini telah terjadi dorongan yang kuat bagi negara-negara berkembang dan transisi untuk melakukan kebijakan desentralisasi seba- gai upaya melepaskan diri dari ketidakefektifan dan ketidakefisiensian pemerintahan, ketidakstabilan makroekonomi, serta rendahnya pertumbuhan ekonomi (Martinez dan McNab. 2005). Menurut Bird (1995), tuntutan mengenai perlunya kebijakan desentralisasi fiskal telah 
menjadi fenomena yang mengglobal pada negara-negara maju maupun negara berkembang guna membenahi sistem keuangan pemerintah daerah dan perimbangan keuangan pusat dan daerah.

Kebijakan desentralisasi merupakan suatu refleksi dalam proses reformasi politik, sosial budaya, dan ekonomi, sehingga perubahan politik dan sosial budaya terutama di negaranegara berkembang telah diwarnai dengan kecenderungan pergeseran pelayanan publik dari wewenang pemerintah pusat beralih menjadi wewenang tingkat pemerintah yang lebih dekat dengan masyarakat. Oleh karena itu, desentralisasi merupakan sebuah alat untuk mencapai salah satu tujuan bernegara dalam memberikan pelayanan publik yang lebih baik dan menciptakan proses pengambilan keputusan publik yang lebih demokratis.

Desentralisasi sesungguhnya memiliki arti perpindahan kekuasaan politik, fiskal, dan administratif dari pemerintah pusat ke unit-unit pemerintah subnasional, sehingga kerangka desentralisasi harus menghubungkan pendanaan lokal dan otoritas fiskal dengan tanggung jawab dan fungsi penyediaan layanan dari pemerintah lokal agar para politisi lokal dapat menanggung biaya keputusan mereka dan menyampaikan janji-janji mereka (Degefa, 2003).

Sebagai upaya penyediaan barang publik, kebijakan desentralisasi fiskal dapat dipandang sebagai transfer keuangan dari pemerintah pusat kepada pemerintah subnasional. Pemerintah subnasional adalah tingkat pemerintahan yang lebih rendah dalam suatu negara. Menurut Boex (2001) menyatakan bahwa transfer keuangan dari pemerintah pusat kepada pemerintah subnasional diwujudkan dalam bentuk transfer Dana Alokasi Umum (DAU) dan Dana Alokasi Khusus (DAK). Sedangkan menurut Hamid (2003), desentralisasi fiskal di Indonesia diwujudkan dalam bentuk dana perimbangan, yang meliputi transfer Bagi Hasil, DAU dan DAK dari pemerintah pusat kepada daerah otonom.

Sejak pelaksanaan desentralisasi fiskal tahun 2001, dana yang dialokasikan ke daerah yang diwujudkan dalam bentuk dana perimbangan, terutama Dana Bagi Hasil (DBH), Dana Alokasi Umum (DAU), dan Dana Alokasi Khu- sus (DAK) telah mengalami peningkatan.

Secara nasional dana yang dialokasikan ke daerah pada tahun 2002-2003 tidak hanya dalam bentuk dana perimbangan saja, tetapi juga dana otonomi khusus dan penyeimbang. Realisasi belanja daerah pada tahun 2001 mencapai Rp81,1 triliun (5,6 persen terhadap PDB), maka pada tahun 2002 meningkat menjadi Rp98,5 triliun (6,1 persen terhadap PDB), atau 21,5 persen lebih tinggi. Sementara dalam APBN tahun 2003, belanja untuk daerah menjadi Rp116,9 triliun (6,0 persen terhadap PDB), atau meningkat sebesar 18,7 persen dari realisasi belanja untuk daerah tahun sebelumnya. Sejalan dengan peningkatan realisasi belanja untuk daerah, maka realisasi dana perimbangan maupun realisasi dana otonomi khusus dan penyeimbang juga cenderung meningkat (Departemen Keuangan, 2004).

Realisasi dana perimbangan, terdiri dari realisasi dana bagi hasil, realisasi dana alokasi umum, dan realisasi dana alokasi khusus. Penerimaan negara yang dibagihasilkan ke daerah melalui APBN meliputi DBH perpajakan dan DBH sumber daya alam (SDA), DBH perpajakan berasal dari pajak penghasilan, khususnya PPh Pasal 21 dan 25/29 orang pribadi, pajak bumi dan bangunan, serta bea perolehan hak atas tanah dan bangunan. Sementara itu, DBH SDA meliputi DBH SDA minyak bumi, SDA gas alam, SDA pertambangan umum, SDA kehutanan, dan SDA perikanan.

Sejak diberlakukannya Undang-undang Nomor 25 Tahun 1999 dan PP Nomor 104 Tahun 2000, alokasi untuk daerah dari bagi hasil minyak bumi dan gas alam masing-masing ditetapkan 15 persen dan 30 persen setelah dikurangi pajak. Namun, sejalan dengan disahkannya Undang-undang Nomor 18 Tahun 2001 tentang Otonomi Khusus bagi provinsi Daerah Istimewa Aceh sebagai provinsi Nangroe Aceh Darussalam (NAD) dan Undang-Undang Nomor 21 Tahun 2001 tentang Otonomi Khusus bagi provinsi Papua, besarnya alokasi dana bagi hasil dari penerimaan minyak bumi dan gas alam untuk kedua provinsi tersebut masing-masing ditetapkan sebesar 70 persen setelah dikurangi pajak. Dengan perkembangan tersebut, dalam tahun 2002 realisasi dana bagi hasil mencapai Rp25,0 triliun, atau meningkat 
sebesar 25,0 persen dari realisasi tahun 2001 yang sebesar Rp20,0 triliun. Sementara itu, dalam APBN tahun 2003, dana bagi hasil ditetapkan sebesar Rp27,9 triliun atau meningkat 11,6 persen dibandingkan dengan realisasi dana bagi hasil tahun 2002.

Pada tahun 2002, realisasi dana alokasi umum mencapai Rp69,1 triliun atau meningkat sebesar 14,4 persen dari realisasi DAU tahun 2001, yang sebesar Rp60,4 triliun. Sementara itu, dalam APBN tahun 2003, dana alokasi umum ditetapkan sebesar Rp77,0 triliun atau meningkat 11,4 persen bila dibandingkan dengan realisasi DAU tahun 2002. Peningkatan DAU tersebut sejalan dengan peningkatan penerimaan dalam negeri bersih. Sedangkan penyaluran DAU untuk masing-masing daerah setiap bulannya ditetapkan sebesar seperduabelas dari pagu yang tercantum dalam alokasi DAU sebagaimana diatur dalam Keppres Nomor 181 Tahun 2000 tentang Dana Alokasi Umum Daerah provinsi dan Daerah Kabupaten/Kota Tahun Anggaran 2001.

Dana Alokasi Khusus (DAK) disediakan kepada daerah untuk memenuhi kebutuhan yang bersifat khusus. Pada awalnya, DAK yang disediakan bagi daerah seluruhnya bersumber dari Dana Reboisasi (DR) yang dialokasikan sebesar 40 persen dari penerimaan dana reboisasi. Namun, mulai tahun 2003 selain untuk membiayai kegiatan reboisasi di daerah penghasil. DAK juga diberikan dalam bentuk DAK Non-DR untuk membiayai kegiatan bidangbidang lain, seperti bidang pendidikan, kesehatan, infrastruktur, dan prasarana pemerintahan daerah pemekaran. Dalam tahun 2002, realisasi DAK DR mencapai Rp0,6 triliun atau menurun sebesar 14,3 persen dari realisasi tahun 2001 sebesar Rp0,7 triliun. Sementara itu, dalam APBN tahun 2003 DAK DR ditetapkan sebesar Rp0,3 triliun atau menurun 50,0 persen dibandingkan dengan realisasi DAK DR tahun 2002. Penurunan tersebut disebabkan oleh berkurangnya penerimaan dana reboisasi dari daerah penghasil. Sementara itu, DAK Non-DR dalam APBN tahun 2003 ditetapkan sebesar Rp2,3 triliun. Alokasi tersebut terdiri dari DAK Non-DR bidang pendidikan 27,5 persen, bidang kesehatan 16,5 persen, bidang infrastruktur 52,0 persen, dan bidang prasarana pemerintahan daerah pemekaran 3,9 persen (Departemen Keuangan, 2004).

Sesuai dengan pasal 7 Undang-undang Nomor 25 Tahun 1999, besarnya dana alokasi umum (DAU) ditetapkan sekurang-kurangnya 25 persen dari penerimaan dalam negeri bersih, yaitu penerimaan dalam negeri setelah dikurangi dengan dana bagi hasil dan DAK yang bersumber dari dana reboisasi. DAU diberikan kepada daerah dengan tujuan untuk menciptakan pemerataan antardaerah berdasarkan pertimbangan bahwa potensi fiskal dan kebutuhan dari masing-masing daerah berbeda. Dengan kata lain, DAU berperan untuk mengatasi kesenjangan horisontal (horizontal imbalance) antardaerah.

Berdasarkan beberapa pertimbangan dan pemikiran tersebut, maka perlu dilakukan penelitian lebih lanjut terhadap pengaruh transfer dana perimbangan terhadap upaya menutup kesenjangan fiskal pada setiap daerah otonom.

Atas dasar beberapa pemikiran pada latar belakang di atas, maka permasalahan dalam penelitian ini adalah bagaimanakah dampak transfer dana perimbangan dari pemerintah pusat kepada pemerintah daerah otonom terutama pada kabupaten dan kota terhadap upaya pemerintah dalam menutup kesenjangan fiskal vertikal (vertical fiscal imbalance)?

Tujuan penelitian ini secara umum adalah untuk mengetahui dan mengkaji secara teoritik dan komprehensif pengaruh transfer dana perimbangan dari pemerintah pusat kepada pemerintah daerah otonom kabupaten dan kota terhadap fenomena Flypaper effect. Penelitian ini secara fokus mengkaji dampak pemerintah pusat melakukan transfer dana perimbangan sebagai upaya menutup kesenjangan fiskal vertikal (vertical fiscal imbalance) pada setiap daerah otonom.

Konsep dan Pengertian Desentralisasi. Desentralisasi merupakan sebuah alat untuk mencapai salah satu tujuan bernegara dalam memberikan pelayanan publik yang lebih baik dan menciptakan proses pengambilan keputusan publik yang lebih demokratis. Desentralisasi merupakan wujud pelimpahan kewenangan kepada tingkat pemerintahan untuk melakukan pembelanjaan, kewenangan memungut pajak 
(taxing power), terbentuknya dewan yang dipilih oleh rakyat, kepala daerah yang dipilih oleh rakyat dan adanya bantuan dalam bentuk transfer dari pemerintah.

Desentralisasi menyangkut berbagai bentuk dan dimensi yang beragam, baik aspek fiskal, politik, administrasi dan sistem pemerintahan, ekonomi, sosial, dan sebagainya. Secara umum konsep desentralisasi terdiri atas: Desentralisasi politik (Political decentralization); Desentralisasi administratif (Administrative decentralization); Desentralisasi fiskal (Fiscal decentralization) dan Desentralisasi ekonomi (Economic or Market Decentralization) (Sidik, 2002).

Berdasarkan UU No. 33 Tahun 2004 dinyatakan bahwa desentralisasi adalah penyerahan wewenang pemerintahan oleh pemerintah kepada daerah otonom untuk mengatur dan mengurus urusan pemerintahan dalam sistem Negara Kesatuan Republik Indonesia. Menurut Studi Bank Dunia yang dilakukan Rondinelli, desentralisasi dapat dibagi menjadi empat jenis, yaitu:

(1) Dekonsentrasi (De-concentration), yaitu pelimpahan wewenang dari pemerintah pusat kepada pejabat yang berada dalam garis hirarki dengan pemerintah pusat di daerah.

(2) Pendelegasian (Delegation), yaitu pelimpahan wewenang untuk tugas tertentu kepada organisasi yang berada di luar struktur birokrasi reguler yang dikontrol secara tak langsung oleh pemerintah pusat. Pendelegasian wewenang ini biasanya diatur dengan ketentuan perundangan. Pihak yang menerima wewenang mempunyai kekuasaan (discretion) dalam penyelenggaraan pendelegasian tersebut, walaupun wewenang terakhir tetap pada pihak pemberi wewenang (Sovereign authority).

(3) Devolusi (Devolution), yaitu pelimpahan wewenang kepada tingkat pemerintahan yang lebih rendah dalam bidang keuangan atau tugas pemerintahan dan pihak pemerintah daerah mendapat discretion yang tidak dikontrol oleh pemerintah pusat. Dalam hal tertentu dimana pemerintah daerah belum sepenuhnya mampu melaksanakan tugasnya, pemerintah pusat akan memberikan supervisi secara tidak langsung atas pelaksanaan tugas tersebut. Dalam melaksanakan tugasnya, pemerintah daerah memiliki wilayah administratif yang jelas dan legal dan diberikan kewenangan sepenuhnya untuk melaksanakan fungsi publik, menggali sumber-sumber penerimaan serta mengatur penggunaannya, serta;

(4) Privatization yaitu pelimpahan wewenang kepada organisasi non pemerintah atau swasta. Hal ini dimaksudkan untuk memberikan peluang bagi organisasi tersebut untuk ambil bagian secara nyata dalam proses pembangunan nasional. Gagasan ini lebih menonjol dalam rangka debirokratisasi dalam arti pengambilan keputusan untuk melaksanakan fungsi-fungsi tertentu dengan melibatkan organisasi-organisasi non pemerintah.

Menurut Bird dan Vaillancourt (1998), serta Martinez dan McNab (2003), desentralisasi secara umum didefinisikan sebagai proses transfer kekuasaan dalam membuat keputusan pada pemerintahan subnasional. Selanjutnya menurut Campo dan Sundaram (2002); Sidik (2002); Martinez dan McNab (1997), menyatakan bahwa desentralisasi dapat dibedakan menjadi:

(1) Desentralisasi geografis atau desentralisasi teritorial, yakni pembagian suatu wilayah menjadi wilayah-wilayah yang lebih kecil dengan kewenangan yurisdiksi yang jelas di antara daerah-daerah tersebut;

(2) Desentralisasi fungsional yakni pendistribusian kewenangan dan tanggungjawab negara kepada unit-unit fungsional yang berbeda-beda dalam suatu pemerintahan;

(3) Desentralisasi politik dan administrasi. Desentralisasi politik berkenaan dengan kewenangan pembuatan keputusan yang bergeser dari pemerintah yang lebih tinggi ke tingkat pemerintahan yang lebih rendah. Dalam konteks ini partisipasi masyarakat lokal dalam proses pembuatan keputusan mendapat peluang yang sangat luas. Sedangkan desentralisasi administrative erat kaitannya dengan desentralisasi politik, bahkan secara faktual keduanya sulit dibedakan. Namun lebih difokuskan pada operasionalisasi atau implementasi kebijakan/ keputusan publik agar berhasil secara optimal.

(4) Desentralisasi finansial, yakni berkaitan dengan pelimpahan tanggung jawab pembelanjaan dan pendapatan dari pemerintah pusat kepada pemerintah daerah.

Menurut Rondinelli (2001) desentralisasi 
didefinisikan sebagai transfer wewenang dan tanggungjawab dalam fungsi-fungsi publik dari pemerintah pusat kepada organisasi pemerintahan yang ada di bawahnya ataupun kepada sektor swasta. Desentralisasi ini dapat dibedakan menjadi desentralisasi politik, administratif, fiskal, dan pasar. Desentralisasi politik bertujuan untuk memberikan kewenangan yang lebih besar kepada warga masyarakat dan wakil pemilih dalam pengambilan keputusan publik. Desentralisasi administratif bertujuan untuk mendistribusikan kekuasaan, tanggung jawab, dan sumber-sumber finansial guna penyediaan pelayanan publik di antara berbagai tingkat pemerintahan yang berbeda. Desentralisasi fiskal merupakan suatu tanggung jawab finansial yang merupakan komponen utama dalam desentralisasi. Jika pemerintah lokal dan organisasi privat dapat melaksanakan fungsi-fungsi desentralisasi secara efektif, maka mereka harus mempunyai penerimaan yang memadai, ditingkatkan secara lokal atau ditransfer dari pemerintah pusat, demikian halnya dengan otoritas untuk membuat keputusan-keputusan tentang pengeluaran. Desentralisasi ekonomi atau pasar adalah bentuk desentralisasi yang paling lengkap dari perspektif pemerintahan. Tipe desentralisasi ini dapat dilakukan dalam bentuk privatisasi dan deregulasi; yaitu pergeseran tanggung jawab untuk fungsi-fungsi dari sektor publik kepada sektor privat.

Tujuan Desentralisasi Fiskal. Pelaksanaan desentralisasi fiskal dan otonomi daerah yang didasarkan Undang-Undang No. 22 Tahun 1999 tentang Pemerintahan Daerah dan UndangUndang No. 25 Tahun 1999 tentang Perimbangan Keuangan Pemerintah Pusat dan Daerah (diganti menjadi UU No. 32 Tahun 2004 dan UU No. 33 Tahun 2004) memberikan kewenangan yang luas dan nyata kepada pemerintah daerah untuk mengelola dan mengatur sumberdaya sesuai dengan kepentingan masyarakat daerahnya, sehingga pemerintah daerah berwenang untuk menetapkan prioritas pembangunan sesuai dengan potensi dan sumberdaya yang dimilikinya.

Misi utama kebijakan desentralisasi fiskal adalah meningkatkan kualitas dan kuantitas pelayanan publik dan kesejahteraan rakyat, terciptanya efektifitas dan efisiensi pengelolaan sumberdaya daerah serta menciptakan ruang bagi masyarakat untuk berpartisipasi dalam proses pembangunan (Mardiasmo, 2001). Alasan lainnya, desentralisasi fiskal didorong karena adanya desakan untuk menyediakan pelayanan-pelayanan pemerintahan yang lebih efisien dan aspiratif (Rao, 2000).

Menurut Hamid (2003), Martinez dan Boex, (2001a) menyatakan bahwa salah satu tujuan dari kebijakan desentralisasi fiskal adalah memperbaiki ketimpangan fiskal vertikal (vertical fiscal imbalance). Kebijakan ini menghendaki adanya tanggungjawab fiskal yang seimbang antara pemerintah pusat dan daerah. Hal ini sesuai teori tradisional federalisme fiskal yang mengidentifikasi terhadap tiga peranan utama untuk sektor publik (Fjeldstad, 2001; Bank Dunia, 2000a; Smoke, 2001) yaitu peranan stabilisasi ekonomi makro, distribusi pendapatan dan alokasi sumberdaya. Teori ini menyebutkan dengan pasti bahwa tugas stabilisasi ekonomi makro dan distribusi merupakan tanggung jawab pemerintah nasional dengan memberikan peranan signifikan dalam mengalokasikan sumberdaya kepada pemerintah subnasional, Fisher (1996) menyatakan bahwa transfer (hibah) dapat dipergunakan diantaranya untuk tujuan mekanisme stabilisasi makroekonomi bagi sektor pemerintah subnasional.

Instrumen Desentralisasi. Menurut Prud'homme (2001) setidaknya terdapat lima instrumen untuk mencapai tujuan desentralisasi, yaitu:

Pertama, pengalokasian tanggung jawab. Barang dan jasa publik sebaiknya disediakan oleh pemerintah. Hanya masalahnya, pada tingkat pemerintahan mana barang dan jasa publik tersebut harus disediakan oleh mereka. Contohnya adalah masalah pendidikan yang perlu mendapatkan perhatian baik pemerintah daerah maupun pusat. Pengalokasian tanggung jawab adalah berkaitan dengan masalah pembagian tanggung jawab yang jelas antara pemerintah pusat dengan tingkat pemerintahan otonom yang berada di bawahnya.

Kedua, alokasi pajak. Barang-barang dan jasa publik setidaknya sebagian besar harus tersedia secara gratis, yang dibiayai dengan pajak. Ada 
sejumlah pajak yang dibatasi, seperti pajakpajak pendapatan pribadi, pajak pendapatan perusahaan, pajak pertamabahan nilai, pajak properti, dan sebagainya. Untuk beberapa pajak bisa dialokasikan secara terus menerus pada beberapa tingkat pemerintahan. Alokasi dalam penetapan pajak pada daerah perdesaan merupakan permasalahan yang sulit. Hal ini dikarenakan daerah perdesaan biasanya sangat miskin. Desa-desa mempunyai obyek/wajib pajak yang sangat sedikit dan mereka hanya dapat membayar dengan tarif pajak yang sangat rendah. Pajak pendapatan dan pajak upah secara perorangan tidak layak untuk dikenakan kepada masyarakat desa; hanya sedikit masyarakat yang mendapatkan upah dan pendapatan yang sangat rendah dan kebanyakan tidak dapat ditelusuri. Pajak pada barang-barang konsumsi juga tidak pantas untuk dikenakan kepada masyarakat perdesaan. Faktor penyebab utama adalah karena kebanyakan apa yang diproduksikan oleh masyarakat desa, secara umum dikonsumsikan sendiri atau diperdagangkan secara barter, dan sangat sulit, kalau tidak dikatakan impossible untuk ditaksir.

Pajak-pajak pada barang-barang yang digunakan sebagai input untuk produksi pertanian seperti pupuk sangat kecil peranannya karena output pertanian juga lebih rendah. Seharusnya pajak-pajak pada produksi barang pertanian dapat dikesampingkan; pajak-pajak itu proporsional, tidak regresif; pajak-pajak itu dapat mengurangi output pertanian jika menciptakan efek harga (harga lebih rendah, output lebih rendah), tetapi sering juga meningkatkan output jika ada efek pendapatan (output yang lebih banyak mempertahankan tingkat pendapatan yang sama). Ada kesulitan juga untuk menaksir pajak tanah, tetapi pajak tanah paling sedikit merusak bentuk pajak, karena pajak tersebut tidak cukup mengecilkan peranan output.

Ketiga, sistem transfer. Teori standar tentang desentralisasi menganggap bahwa tanggung jawab dan pajak akan didesentralisasikan secara bersama-sama, dan setiap tingkat pemerintahan akan membiayai pengeluarannya sendiri. Dalam banyak negara, tanggung jawab lebih didesentralisasikan dari pada pajak dan pem- biayaan ditransfer dari pemerintah pusat ke pemerintah subnasional. Hal ini dapat dilakukan dengan banyak cara dan sistem transfer antarpemerintahan dapat dirancang.

Keempat, kontrol pemerintah pusat, Desentralisasi adalah tentang pemindahan kekuasaan dari pemerintah pusat ke pemerintah subnasional. Pemindahan kekuasaan (transfer) ini bukan secara total maupun sempurna. Di manapun juga, pemerintahan pusat menguasai beberapa bentuk dari kontrol atas apa yang pemerintah pusat lakukan dalam kaitan dengan pengeluaran, pinjaman, perpajakan, penganggaran, accounting, pelaporan, audit, dan lainlain.

Kelima, peraturan pemilihan pemerintah lokal. Tidak ada desentralisasi tanpa kebebasan secara relatif dan respons pemerintah lokal secara politis. Aturan-aturan yang mengatur tentang bentuk dan fungsi pemerintah lokal adalah bagian yang integral dari desentralisasi. Hal ini termasuk aturan-aturan pemilihan (bagaimana memilih dewan dan walikota, untuk berapa lama, berapa banyak waktu yang dibutuhkan), tetapi juga aturan-aturan administrasi seperti bagaimana pengajuan anggaran dan implementasinya. Hal lainnya menyangkut struktur subnasional seperti berapa banyak tingkat pemerintahan, berapa luas wilayah, penduduk, provinsi dan kabupaten/kota.

Kebijakan Desentralisasi dan Flypaper Effect Theory. Tujuan utama pemerintah pusat memberikan transfer keuangan adalah membantu meningkatkan permintaan agregate pemerintah lokal melalui peningkatan pengeluarannya. Kebijakan transfer keuangan ini banyak dialamatkan bagi daerah-daerah yang secara ekonomi masih miskin sehingga transfer keuangan dapat dianggap sebagai subsidi bagi masyarakat lokal. Menurut Hines dan Thaler (1995), jika pemerintah lokal menerima suatu hibah maka akan dipergunakan untuk meningkatkan pengeluarannya tanpa meningkatkan pajak

Roemer dan Silvestre (2000) berpendapat bahwa flypaper effect secara umum dapat dipahami sebagai ketidaksepadanan pengaruh pengeluaran publik dari bantuan pemerintah federal dan peningkatan pendapatan dengan jumlah yang sama. Berapapun bantuan peme- 
rintah pusat kepada pemerintah daerah harus memberikan pengaruh yang sama besarnya. Sebagai contoh adalah bahwa setiap rupiah yang dikeluarkan oleh pemerintah pusat sebagai bantuan kepada pemerintah daerah, mestinya memberikan pengaruh yang sama besar yaitu sebesar satu rupiah pada peningkatan pendapatan pemerintah atau masyarakat lokal. Bila hal ini tidak terjadi, di mana ada kecenderungan bahwa pengaruh pengeluaran publik dalam bentuk bantuan pemerintah pusat kepada pemerintah daerah tidak memberikan pengaruh yang sama besarnya maka hal inilah yang disebut flypaper effect. Interpretasi tentang flypaper effect ini diturunkan dari masalah "penumpang gratis" (free-riding) antara pemerintah pusat dengan pemerintah lokal. Di sini pemerintah lokal mendapatkan keuntungan dengan terus meningkatkan pengeluaran lokal mereka apabila pengeluaran ini dibiayai dengan transfer keuangan pemerintah pusat, karena pemerintah lokal tidak akan sama sekali membayar apa-apa (gratis), sebagai share dari tingkat nasional.

Dengan merilis pendapat Oates (1999), Legrenzi dan Milas (2002) bahwa diskusi tentang flypaper effect sudah secara umum mengabaikan isu-isu tentang apakah pemerintah lokal merespons/menanggapi perubahan dengan adanya transfer keuangan pemerintah pusat sebagai hal yang simetrik atau asimetrik, kendati pendekatan ini bertujuan untuk lebih memberikan harapan yang berarti dan berguna kepada masyarakat lokal. Hal tersebut mungkin bahwa flypaper effect hanya beroperasi dalam satu arah saja, yaitu yang berkenaan dengan peningkatan dari pada pengurangan dalam transfer pemerintah pusat. Hipotesis semacam ini disebut "fiscal replacement" karena pemerintah lokal akan menempuh upayaupaya yang lebih tinggi untuk meningkatkan bentuk-bentuk penerimaan yang lain untuk menjamin program-program pengeluarannya. Alternatifnya adalah, jika flypaper effect beroperasi dalam dua arah (simetris), pemerintah lokal akan mengurangi pengeluaran mereka sebagai suatu konsekwensi dari pengurangan dalam transfer pemerintah pusat yang diterima (Langoday, 2006).

Tinjauan Empirik. Menurut Thomas (2006:
52), bantuan keuangan antarpemerintah dalam suatu negara sering disebut dengan transfer keuangan antarpemerintah (intergovernmental transfer=intergovernmental hibahs atau sering disebut juga hibahs-in-aid), yaitu transfer dana dari satu tingkatan pemerintahan ke tingkat pemerintahan yang lain, dan kebanyakan dari tingkat pemerintahan yang lebih tinggi ke tingkat pemerintahan yang lebih rendah dalam suatu negara. Apabila pemerintah lokal menerima hibah, maka akan dipergunakan untuk meningkatkan pengeluarannya tanpa meningkatkan pajak. Terjadinya penyimpangan dari semestinya dalam hubungan transfer keuangan pemerintah pusat dengan penerimaan atau pengeluaran pemerintah lokal disebut flypaper effect; bila terjadi penyimpangan karena peningkatan pengeluaran lebih besar dari pada pajak lokal dalam merespons hibah disebut fiscal replacement effect (Hines Jr dan Thaler,1995: 223).

Bantuan bagi pemerintah daerah harus dipandang dari dua sisi, yaitu pengaruh terhadap pengeluaran dan juga pengaruh terhadap pajak dan pendapatan. Secara empirik efek hibah pada pengeluaran kebanyakan lebih besar dari pada efek terhadap pendapatan (Gemmell, Morrissey dan Pinar (1998:2). Perubahan dalam hibah pemerintah pusat mempunyai dampak yang lebih besar terhadap pengeluaran lokal ketimbang terhadap pajak lokal. Penelitian Gemmell, Morrissey dan Pinar (1998:23) di Inggris dan Walles menunjukkan bahwa satu unit peningkatan dalam hibah menyebabkan peningkatan yang jauh lebih besar dalam pengeluaran lokal per kapita (sekitar 0,75 per unit), dibandingkan dengan peningkatan dalam pendapatan rata-rata (kurang dari 0,2 per unit). Sedangkan menurut Durcan dan Smith (1996: 108), menyatakan bahwa tingkat hibah pemerintah pusat merupakan determinan yang penting bagi tingkat pengeluaran pemerintah lokal. Dampak hibah pemerintah pusat terhadap pendapatan lokal dan pengeluaran lokal secara jelas dan nyata menunjukkan adanya flypaper effect. Hibah pemerintah pusat tampaknya menstimulasi pengeluaran jauh lebih besar dari pada pendapatan lokal.

Flypaper effect secara umum dipahami sebagai ketidaksamaan pengaruh pengeluaran 
publik dari bantuan pemerintah federal dan peningkatan pendapatan dengan jumlah yang sama. Berapapun bantuan pemerintah pusat kepada pemerintah daerah harus memberikan pengaruh yang sama besarnya. Sebagai contoh adalah bahwa setiap rupiah yang dikeluarkan oleh pemerintah pusat sebagai bantuan kepada pemerintah daerah, mestinya memberikan pengaruh yang sama besar yaitu sebesar satu rupiah pada peningkatan pendapatan pemerintah atau masyarakat lokal. Bila hal ini tidak terjadi, di mana ada kecenderungan bahwa pengaruh pengeluaran publik dalam bentuk bantuan pemerintah pusat kepada pemerintah daerah tidak memberikan pengaruh yang sama besarnya maka hal inilah yang disebut flypaper effect (Roemer dan Silvestre, 2000: 20).

Dalam literatur-literatur ekonomi tradisional tentang pola penerimaan dan pengeluaran pemerintah lokal sudah sangat menekankan eksistensi daripada flypaper effect. Teori ini menggambarkan adanya perbedaan respons dari pemerintah lokal yang berkenaan dengan perubahan dalam pendapatan sendiri dan dengan perubahan dalam transfer keuangan pemerintah pusat. Pemerintah lokal secara konsisten meningkatkan pengeluaran mereka lebih berkenaan dengan peningkatan dalam transfer keuangan pemerintah pusat daripada dengan meningkatkan penerimaan mereka sendiri. Tentu saja flypaper effect menggambarkan penyimpangan dari yang biasa (anomali) dalam perilaku rational, karena transfer keuangan pemerintah pusat dianggap sebagai suatu tambahan pendapatan bagi masyarakat (Legrenzi dan Milas, 2002).

Menurut Oates (1999) Legrenzi dan Milas (2002:2), bahwa diskusi tentang flypaper effect sudah secara umum mengabaikan isu-isu tentang apakah pemerintah lokal merespons/ menanggapi perubahan dengan adanya transfer keuangan pemerintah pusat sebagai hal yang simetrik atau asimetrik, kendati pendekatan ini bertujuan untuk lebih memberikan harapan yang berarti dan berguna kepada masyarakat lokal. Hal tersebut mungkin bahwa flypaper effect hanya beroperasi dalam satu arah saja, yaitu yang berkenaan dengan peningkatan dari pada pengurangan dalam transfer pemerintah pusat. Hipotesis semacam ini disebut "fiscal replacement" karena pemerintah lokal akan menempuh upaya-upaya yang lebih tinggi untuk meningkatkan bentuk-bentuk penerimaan yang lain untuk menjamin program-program pengeluarannya. Alternatifnya adalah, jika flypaper effect beroperasi dalam dua arah (simetris), pemerintah lokal akan mengurangi pengeluaran mereka sebagai suatu konsekwensi dari pengurangan dalam transfer pemerintah pusat yang diterima.

Lebih lanjut, Rosen (2002:502) mengatakan bahwa berbagai bentuk hibahs sebenarnya ditujukan untuk kepentingan median voter. Birokrat dan legislatif hanya memainkan peran pasif dalam mengimplementasikan keinginan daripada median voter. Harus diakui bahwa keinginan daripada median voter adalah bahwa setiap rupiah yang diberikan sebagai bantuan harus secara mutlak/utuh diterima sebagai pendapatan. Namun demikian, sesungguhnya setiap studi menyimpulkan bahwa setiap rupiah yang diterima oleh masyarakat sebagai bantuan menghasilkan pengeluaran pemerintah yang lebih besar dari pada satu rupiah peningkatan pendapatan masyarakat. Secara kasar dapat dikatakan bahwa satu rupiah yang diterima sebagai bantuan menghasilkan 40 sen pengeluaran pemerintah, sementara tambahan satu rupiah pendapatan swasta, meningkatkan pengeluaran pemerintah hanya 10 sen. Fenomena semacam ini diberi julukan flypaper effect.

Penjelasan tentang flypaper effect berfokus pada aturan birokrat. Dengan merilis pendapat Filimon, Romer dan Rosenthal (1982), Rosen (2002:503) mengemukakan bahwa birokrat bertujuan untuk memaksimisasi besarnya anggaran. Sebagai budget maximizer, birokrat tidak mempunyai insentif untuk menginformasikan kepada masyarakat tentang besarnya dana bantuan yang sesungguhnya diterima masyarakat. Dengan menyembunyikan informasi ini, birokrat dapat menipu masyarakat tetapi selalu melaporkan kepada atasan bahwa masyarakat menerima bantuan sesuai dengan ketentuan/ haknya. Menurut tinjauan ini, flypaper effect terjadi karena masyarakat tidak paham tentang kendala anggaran yang benar. Untuk mendukung teori mereka, Filimon, Romer dan Rosenthal menulis bahwa dalam negara dengan referendum langsung di mana terdapat pertanyaan 
pembelanjaan, surat suara sering berisi informasi tentang tarif pajak (tax base) tetapi jarang mempunyai data tentang bantuan (hibahs).

Hasil penelitian Legrenzi dan Milas di Italia (2002:7) dalam kaitan dengan hubungan antara pengeluaran pemerintah lokal/kotamadya (LG), transfer dari pemerintah pusat yang diterima pemerintah lokal (LTR), dan pajak yang diterima pemerintah lokal (LTAX) telah menimbulkan adanya "flypaper effect". Flypaper effect dalam penelitian tersebut ditunjukkan dengan koefisien transfer yang positif dan tinggi di mana setiap 10 persen peningkatan transfer keuangan pemerintah pusat, akan meningkatkan pengeluaran pemerintah kabupaten sebesar 7 persen. Pada sisi lain, hubungan antara pajak lokal dengan transfer keuangan pemerintah pusat adalah positif, menunjukkan adanya kemungkinan kolaborasi antara pemerintah pusat dan daerah; pajak daerah meningkat dengan 4,6 persen dalam merespons 10 persen peningkatan transfer keuangan pemerintah pusat. Peningkatan transfer keuangan pemerintah pusat tidak membawa keringanan pajak bagi masyarakat; peningkatan pengeluaran yang lebih besar daripada pajak lokal dalam merespons peningkatan transfer inilah yang disebut sebagai Fiscal Replacement Effect. Selanjutnya Rodden (2002:1), menyatakan bahwa transfer keuangan pemerintah pusat masih menjadi primadona sumber penerimaan bagi pemerintah daerah ketimbang pajak daerah. Lebih lanjut dikatakan bahwa konsisten dengan argumen teoritis dalam ilmu ekonomi kesejahteraan dan ekonomi politik positif, yaitu bahwa pengeluaran publik pemerintah lokal bertumbuh lebih cepat melalui intergovernmental transfer daripada dengan pajak lokal.

Hasil penelitian Thomas (2006) yang dilakukan di provinsi Nusa Tenggara Timur menemukan bahwa transfer pemerintah pusat pada pemerintah daerah mempengaruhi ketimpangan fiskal vertikal (kemandirian fiskal). Semakin meningkatnya ketimpangan fiskal vertikal akan memberikan dampak terhadap penurunan kebutuhan fiskal.

Hasil penelitian tersebut sesuai dengan tujuan dana desentralisasi fiskal untuk mendorong peningkatan kebutuhan fiskal daerah, dimana dana desentralisai fiskal adalah diper- gunakan untuk membangun sarana dan prasarana publik dalam bidang pemerintahan, pembangunan dan kemasyarakatan. Dengan demikian, sekaligus diharapkan dapat mendorong tingkat pertumbuhan ekonomi daerah yang selanjutnya meningkatkan kesejahteraan hidup masyarakat. Implikasi hasil penelitian tersebut bahwa peningkatan ketimpangan fiskal vertikal berarti terjadi penurunan ekonomi daerah dan kesejahteraan masyarakat. Dengan penurunan ekonomi dan kesejahteraan masyarakat berarti mereka belum mampu untuk membiayai kebutuhan fiskal mereka.

\section{METODE PENELITIAN}

\section{Jenis Penelitian}

Secara umum penelitian ini mengg unakan rancangan penelitian penjelasan (explanatory research). Penelitian ini untuk menguji secara empirik hubungan dan pengaruh antara variabelvariabel dana desentralisasi terhadap ketimpangan fiskal vertikal.

\section{Obyek Penelitian}

Penelitian ini difokuskan pada Anggaran Pendapatan dan Belanja Daerah (APBD) baik dari sisi penerimaan maupun pengeluaran APBD daerah otonom Kabupaten dan Kota di Provinsi Jawa Timur setelah diberlakukannya UU No. 22 Tahun 1999 dan UU No. 25 Tahun 1999 yang kemudian diganti dengan UU No. 32 Tahun 2004 dan UU No. 33 Tahun 2004.

\section{Unit Analisis}

Penelitian ini dilakukan pada pemerintah kabupaten dan kota di provinsi Jawa Timur. Provinsi ini sampai dengan tahun 2006 memiliki 30 kabupaten dan 8 kota. Untuk kepentingan analisis agar lebih lengkap, kota hasil pemekaran, khususnya kota Batu dimasukkan dalam objek penelitian, kota ini menjadi daerah otonom baru sejak tahun 2001 dari hasil pemekaran kabupaten Malang. Dengan demikian, unit analisis penelitian ini terdiri atas 30 kabupaten dan 8 kota. 


\section{Data Penelitian}

Data yang digunakan pada penelitian ini adalah data sekunder. Sebagian besar data sekunder ini berasal dari Biro Keuangan Setda Provinsi Jawa Timur, Badan Pusat Statistik (BPS) Jawa Timur dan BPS pada masing-masing kabupaten dan kota.

\section{Definisi Operasional dan Pengukuran Variabel}

Definisi operasional merupakan penjelasan tentang bagaimana operasi atau kegiatan yang dilakukan untuk memperoleh data atau indikator pada penelitian. Variabel penelitian ini meliputi dana desentralisasi dalam bentuk dana dana perimbangan, yaitu; DAU, DAK, dan BHPP; koefisien ketimpangan fiskal vertikal; dan Flypaper effect. Untuk mengoperasionalkan masing-masing variabel penelitian, maka disusun definisi operasional sebagai berikut:

(1) Dana Bagi Hasil Pajak dan Bukan Pajak (BHPP) adalah dana transfer dari pemerintah pusat kepada daerah otonom kabupaten dan kota dalam bentuk bagi hasil pajak maupun sumber daya alam. Pengukuran besarnya dana ini dinyatakan dalam satuan miliar rupiah.

(2) Dana Alokasi Umum (DAU) adalah dana transfer dari pemerintah pusat kepada daerah otonom kabupaten dan kota dalam bentuk block hibah. Pengukuran besarnya dana ini dinyatakan dalam satuan miliar rupiah.

(3) Dana Alokasi Khusus (DAK) adalah dana transfer dari pemerintah pusat kepada daerah otonom kabupaten dan kota dalam bentuk specific hibah. Pengukuran besarnya dana ini dinyatakan dalam satuan miliar rupiah.

(4) Dana Desentralisasi (DD) adalah transfer keuangan yang berupa dana perimbangan dari pemerintah pusat kepada pemerintah daerah otonom dalam bentuk Dana Bagi Hasil Pajak dan Bukan Pajak (BHPP). Dana Alokasi Umum (DAU) dan Dana Alokasi Khusus (DAK). Besarnya dana perimbangan ini dinyatakan dalam satuan miliar rupiah.

(5) Variabel Ketimpangan Fiskal Vertikal (KFV) menunjukkan adanya disparitas antara kapasitas/potensi fiskal dan kebutuhan fiskal antara pemerintah pusat dengan tingkat pemerintahan yang lebih rendah (dalam penelitian ini adalah pemerintah kabupaten dan kota). Pengukuran besarnya ketimpangan fiskal vertikal dilakukan menggunakan formula dari Shah dan Qureshi (1994), Hunter (1977), dan Hamid (2003) sebagai berikut:

$$
K F V=1-\left[\frac{D A U+D A K+B H P P}{E X P}\right]
$$

di mana: KFV adalah koefisien ketimpangan fiskal vertikal daerah otonom, DAU adalah dana alokasi umum untuk periode setelah otonomi, DAK adalah dana alokasi khusus untuk periode setelah otonomi, BHPP adalah dana bagi hasil pajak dan bagi hasil bukan pajak, EXP adalah total pengeluaran daerah pada APBD.

\section{Model dan Teknik Analisa Data}

Analisis pengujian penelitian ini menggunakan program Eviews. Menurut Winarno, W (2007), Eviews adalah program komputer yang digunakan untuk mengolah data statistik dan data ekonometri. Program ini dapat digunakan untuk menyelesaikan masalah-masalah yang berbentuk time series, cross section, maupun data panel. Data panel adalah data yang bersifat time series dan cross section, sehingga terdiri atas beberapa objek dan meliputi beberapa periode. Model Persamaan Untuk Mengestimasi Pengaruh Variabel Dana Desentralisasi terhadap Variabel Koefisien Ketimpangan Fiskal Vertikal sebagai efek dari kebijakan desentralisasi fiskal.

Model persamaan penelitian ini mengacu pada model penelitian Langoday (2006) serta Hamid (2003), Secara matematis koefisien ketimpangan fiskal vertikal (KFV) dirumuskan:

$\mathrm{KFV}=\mathrm{f}(\mathrm{DD})$

dimana: KFV adalah ketimpangan fiskal vertikal daerah otonom, DD adalah dana desentralisasi daerah otonom. Model persamaan untuk mengestimasi pengaruh dana desentralisasi (DD) terhadap koefisien Ketimpangan Fiskal Vertikal (KFV) pada kabupaten dan kota dirumuskan sebagai berikut:

$\mathrm{KFV}_{\text {it }}=\beta_{0}+\beta_{1} \mathrm{DD}_{\mathrm{it}}$.

di mana: $\boldsymbol{\beta}_{0}$ adalah konstanta, $\boldsymbol{\beta}_{\mathbf{1}}$ adalah koefisien regresi. 


\section{HASIL ANALISIS DAN PEMBAHASAN}

Secara umum bantuan (hibahs) pemerintah pusat kepada pemerintah daerah dapat dibedakan ke dalam dua bentuk, yaitu bantuan umum atau blok (general hibah/block hibah/ unconditional hibahs) yaitu bantuan kepada pemerintah daerah yang tidak disertai dengan ikatan atau syarat tertentu dalam arti daerah dapat menggunakan/mengalokasikannya kepada penggunaan-penggunaan yang dikehendaki oleh daerah yang bersangkutan; serta bantuan khusus (specific hibahs/conditional hibahs), yaitu bantuan yang diberikan kepada daerah untuk menyediakan pelayanan atau jasa-jasa publik yang sudah ditentukan oleh pemerintah pusat (PAU UGM, 2000).

Perbedaan kedua bantuan tersebut terletak pada dampak yang ditimbulkannya. Bantuan umum (Unconditional Hibahs) merupakan jenis transfer yang memberikan kebebasan (discretion) bagi daerah penerima untuk mengalokasikannya sesuai dengan preferensi dan prioritas daerah. Pengalokasian bantuan umum dimaksudkan sebagai dana pendukung dalam pelaksanaan program pembangunan yang menjadi prioritas daerah. Pemerintah pusat tidak terlibat langsung dalam menentukan pengalokasian bantuan tersebut. Sebaliknya apabila bantuan yang diberikan oleh pemerintah pusat dalam bentuk bantuan khusus (Selective Hibahs), maka pengalokasiannya telah ditentukan. Penentuan ini bisa bersumber dari pemberi bantuan maupun penerima bantuan. Bentuk bantuan ini bisa murni atau dibiayai sepenuhnya oleh pemberi bantuan tanpa melibatkan anggaran daerah penerima bantuan dalam bentuk tanggung renteng (sharing-cost). Sedangkan bantuan khusus murni (Nonmatching Selective Hibahs) ditujukan untuk mendanai suatu program/proyek tertentu yang ditetapkan oleh pemberi bantuan. Bantuan khusus murni dilakukan dengan mengalokasikan sejumlah dana untuk membiayai suatu program/proyek tertentu, tanpa ada keharusan melibatkan sumber dana dari daerah penerima bantuan. Jenis ini sangat tepat untuk membiayai proyek-proyek/program pemerintah pusat, misalnya program $\mathrm{KB}$, imunisasi folio, imunisasi campak, dan sebagainya.
Tepat tidaknya pemberian kedua bantuan di atas sangat tergantung pada tujuan pemberian bantuan itu sendiri. Apabila tujuan pemberian bantuan tersebut adalah untuk mendorong jenis-jenis pengeluaran tertentu oleh pemerintah penerima, maka bantuan atau subsidi dalam bentuk conditional matching hibahs atas pengeluaran tersebut lebih sesuai. Jika tujuan pemberian bantuan adalah semata-mata untuk pengalihan daya beli (transfer of purchasing power) dari tingkat pemerintahan yang lebih tinggi kepada tingkat pemerintahan yang lebih rendah, maka bantuan dalam bentuk unconditional hibahs adalah lebih sesuai (Boadway dan Wildasin, 1984).

Bantuan pembangunan dalam bentuk bantuan umum, pemerintah daerah berwenang menentukan untuk apa bantuan itu digunakan, asal saja dipakai untuk sektor-sektor yang tepat, sesuai dengan program yang telah disetujui sebelumnya. Sedangkan bantuan yang bersifat khusus, pemerintah pusat menetapkan prioritas dan pembagian dana, sementara pemerintah daerah hanya berwenang dalam hal penentuan lokasi proyek dan cara melaksanakannya (Devas, Nick, Binder, Booth, Davey dan Kelly, 1988). Ciri khusus yang menjadi kekuatan utama jenis bantuan umum adalah dapat meningkatkan sumberdaya lokal, sekaligus mempertahankan pilihan fiskal (fiscal choice) yang ada dalam kewenangan pemerintah daerah, Pemerintah daerah memiliki kebebasan dalam mengalokasikan dana yang diterima ke dalam berbagai kemungkinan pengeluaran yang sesuai dengan pilihan dan kepentingan daerah yang bersangkutan. Sedangkan menurut Shah (1995) terdapat empat kriteria untuk menilai efektifitas sistem transfer dari pusat ke daerah. Pertama, Pemerintah daerah harus dapat membiayai seluruh pengeluarannya untuk pelayanan jasa publik dari sumber penerimaannya (revenue adequacy), baik dari sumberdaya yang ada maupun dari transfer tersebut. Kedua, sistem transfer harus tidak mendorong terjadinya anggaran yang defisit. Pemerintahan di daerah harus tetap berusaha untuk mengoptimalkan pajak daerah dan mengontrol pengeluarannya. Ketiga, transfer haruslah berbanding lurus dengan kebutuhan fiskal daerah dan berbanding terbalik dengan kapasitas fiskal daerah. Keem- 


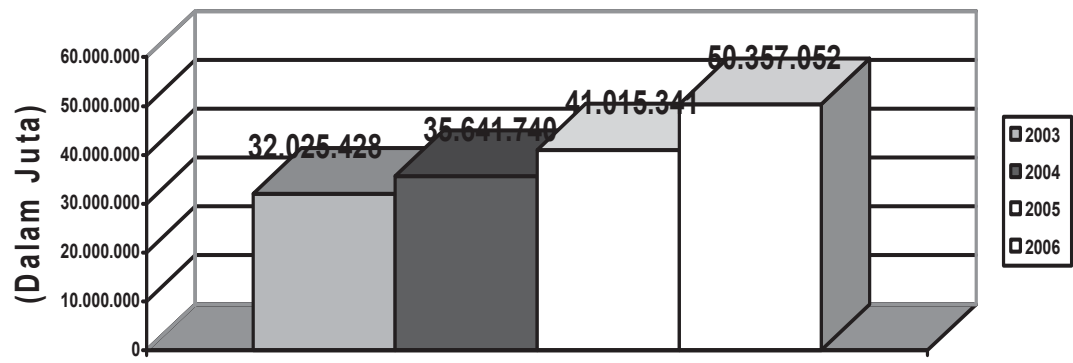

Sumber: Data APBD Kabupaten dan Kota Provinsi Jawa Timur Diolah

Gambar 1. Bagi Hasil Pajak dan Bukan Pajak (BHPP) pada Kabupaten dan Kota Provinsi Jawa Timur Tahun 2003-2006

sejak tahun 2003-2006 mengalami peningkatan, Rata-rata penerimaan DAU pada daerah otonom kabupaten dan kota di provinsi Jawa Timur dapat dilihat pada Gambar 2.

Rata-rata penerimaan DAU tahun 2003 sebesar Rp255.036.487 miliar, meningkat menjadi Rp264.667.974 miliar pada tahun 2004, kemudian naik menjadi Rp279.792.211 miliar pada tahun 2005, sedangkan tahun 2006 menjadi Rp415.683.868 miliar.

(3) Dana Alokasi Khusus (DAK). Rata-rata penerimaan dana alokasi khusus (DAK) pemerintah kabupaten dan kota di provinsi Jawa Timur sejak tahun 2003-2006 mengalami peningkatan, yaitu sebesar Rp5.050.625 miliar untuk tahun 2003, meningkat menjadi Rp6.667.482 miliar pada tahun 2004, naik menjadi Rp7.118.026 miliar pada tahun 2005, serta menjadi Rp24.048.398 miliar untuk tahun 2006. Histogram penerimaan DAK daerah otonom kabupaten dan kota di provinsi Jawa Timur tahun 2003-2006 dapat dilihat pada Gambar 3.
Perkembangan Dana Desentralisasi pada Daerah Otonom Kabupaten dan Kota

Penelitian ini menemukan besarnya dana desentralisasi yang berupa dana perimbangan sejak tahun 2003 sampai dengan 2006 mengalami peningkatan. Rata-rata penerimaan dana perimbangan pemerintah kabupaten dan kota di provinsi Jawa Timur sejak tahun 2003-2006, yaitu sebesar Rp292.112.541 miliar untuk tahun 2003, meningkat menjadi Rp306.977.196 miliar pada tahun 2004, kemudian naik menjadi Rp327.925.578 miliar pada tahun 2005, serta menjadi Rp490.089.318 miliar untuk tahun 2006. Rata-rata penerimaan dana perimbangan daerah otonom kabupaten dan kota di provinsi Jawa Timur dapat dilihat pada Gambar 4.

Perkembangan Koefisien Ketimpangan Fiskal Vertikal Daerah Otonom Pemerintah Kabupaten dan Kota

Hasil penelitian ini menemukan bahwa besarnya koefisien ketimpangan fiskal vertikal kabupaten dan kota di provinsi Jawa Timur sebesar

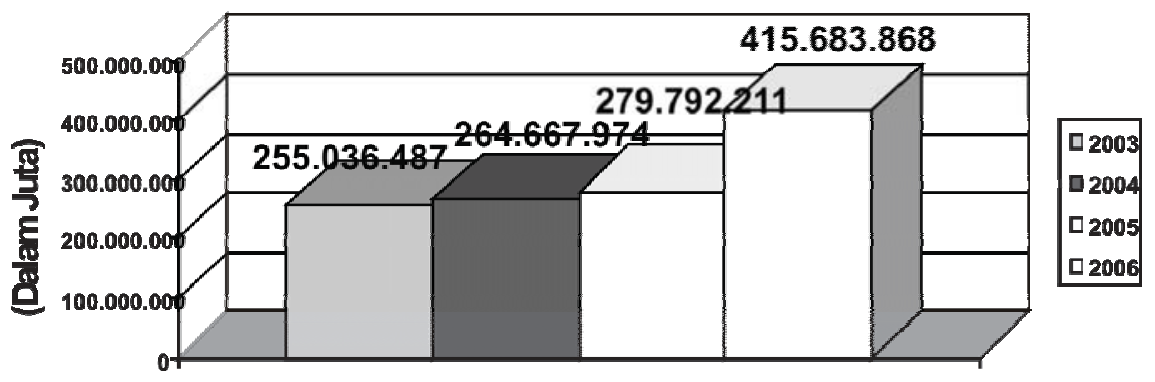

Sumber: Data APBD Kabupaten dan Kota Provinsi Jawa Timur Diolah

Gambar 2. Dana Alokasi Umum (DAU) pada Kabupaten dan Kota di Provinsi Jawa Timur Tahun 2003-2006 
24.048.398

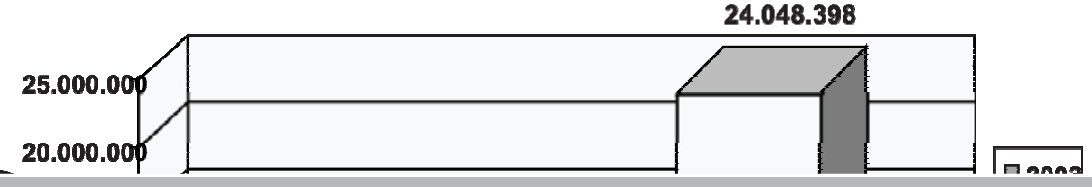




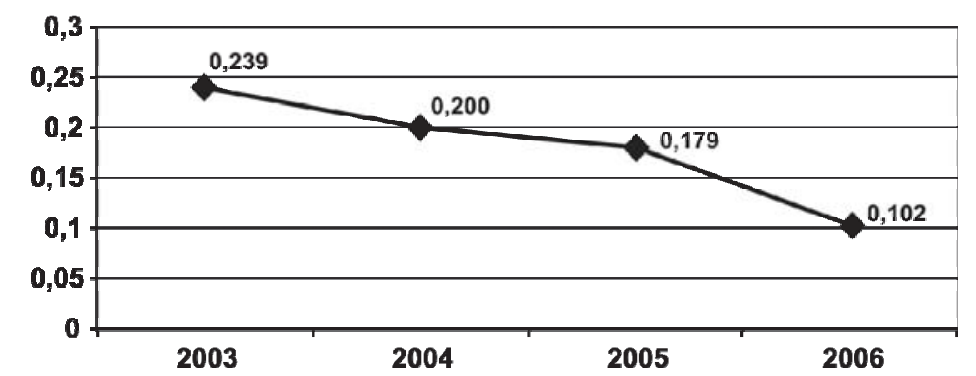

Sumber: Data APBD Kabupaten dan Kota di Provinsi Jawa Timur Diolah

\section{Gambar 5. Perkembangan Koefisien Ketimpangan Fiskal Vertikal pada Kabupaten dan Kota di Provinsi Jawa Timur Tahun 2003-2006}

fiskal vertikal daerah otonom dapat dilihat pada Tabel 1.

Model persamaan berdasarkan hasil analisis adalah:

$K F V=0,213234-9,37 \mathrm{E}-11 D D$

t $\quad 11,25113-1,909581$

$R^{2}=\quad 0,0237 r=-0,154$

Prob. $\quad 0,0000 \quad 0,0568$

Apabila persamaan 4 diuraikan, maka akan terlihat besarnya koefisien beta pada variabel dana desentralisasi (DD) sebesar -9,37E-11. Hal ini menunjukkan bahwa peningkatan dana desentralisasi (DD) akan meningkatkan ketimpangan fiskal secara vertikal (KFV) atau peningkatan dana desentralisasi mendorong peningkatan pengeluaran daerah tidak sebanding dengan peningkatan kapasitas fiskal daerah otonom. Daerah otonom semakin tergantung dana transfer untuk membiayai pengeluarannya. Pengeluaran ini terutama untuk belanja aparatur maupun belanja pelayanan publik daerah otonom. Tingkat keberartian pengaruh variabel dana desentralisasi (DD) terhadap variabel koefisien ketimpangan fiskal vertikal (KFV) secara statistik dapat diuji menggunakan uji-t.

Berdasarkan hasil uji-t, variabel dana desentralisasi (DD) secara statistik memberikan pengaruh yang signifikan terhadap koefisien ketimpangan fiskal vertikal (KFV). Hal ini terbukti dari nilai thitung sebesar $-1,9096$. Nilai ini lebih besar dari $t$ tabel $(-1,9096>-1,645)$ dan nilai probabilitas sebesar 0,0568 , nilai ini lebih kecil dari $\alpha=0,10$. Dengan demikian secara statistik H1 diterima, Artinya, hipotesis yang menyatakan "ada pengaruh yang signifikan dari variabel dana desentralisasi terhadap koefisien ketimpangan fiskal vertikal" dapat dibuktikan kebenarannya. Hasil analisis yang telah diuraikan di atas dapat dilihat pada Gambar 6.

Salah satu tujuan desentralisasi fiskal adalah mengatasi ketimpangan fiskal vertikal daerah otonom. Terjadinya ketimpangan fiskal vertikal daerah otonom kabupaten dan kota disebabkan karena pemerintah pusat menguasai sebagian besar pendapatan yang bersumber dari daerah otonom, sehingga dengan minimnya pendapatan daerah otonom dapat mengakibatkan menurunnya tingkat pelayanan

Tabel 1. Pengaruh Dana Desentralisasi terhadap Koefisien Ketimpangan Fiskal Vertikal Daerah Otonom Di Jawa Timur

\begin{tabular}{|c|c|c|c|c|c|}
\hline $\begin{array}{l}\text { Variabel } \\
\text { Konstanta } \\
\text { DD }\end{array}$ & & $\begin{array}{l}\text { Coefficients } \\
0,213234 \\
-9,37 \mathrm{E}-11\end{array}$ & $\begin{array}{c}\mathbf{t} \\
-1,9096\end{array}$ & $\begin{array}{c}\text { Sig } \\
0,0568\end{array}$ & $\begin{array}{l}\text { Keterangan } \\
\text { * signifikan }\end{array}$ \\
\hline R Square $\left(\mathrm{R}^{2}\right)$ & $=0,0237$ & & & & \\
\hline $\begin{array}{l}\text { T tabel } \\
\alpha\end{array}$ & $\begin{array}{l}=1,645 \\
=0,10\end{array}$ & & & & \\
\hline
\end{tabular}

Sumber: Data sekunder diolah (2008) 


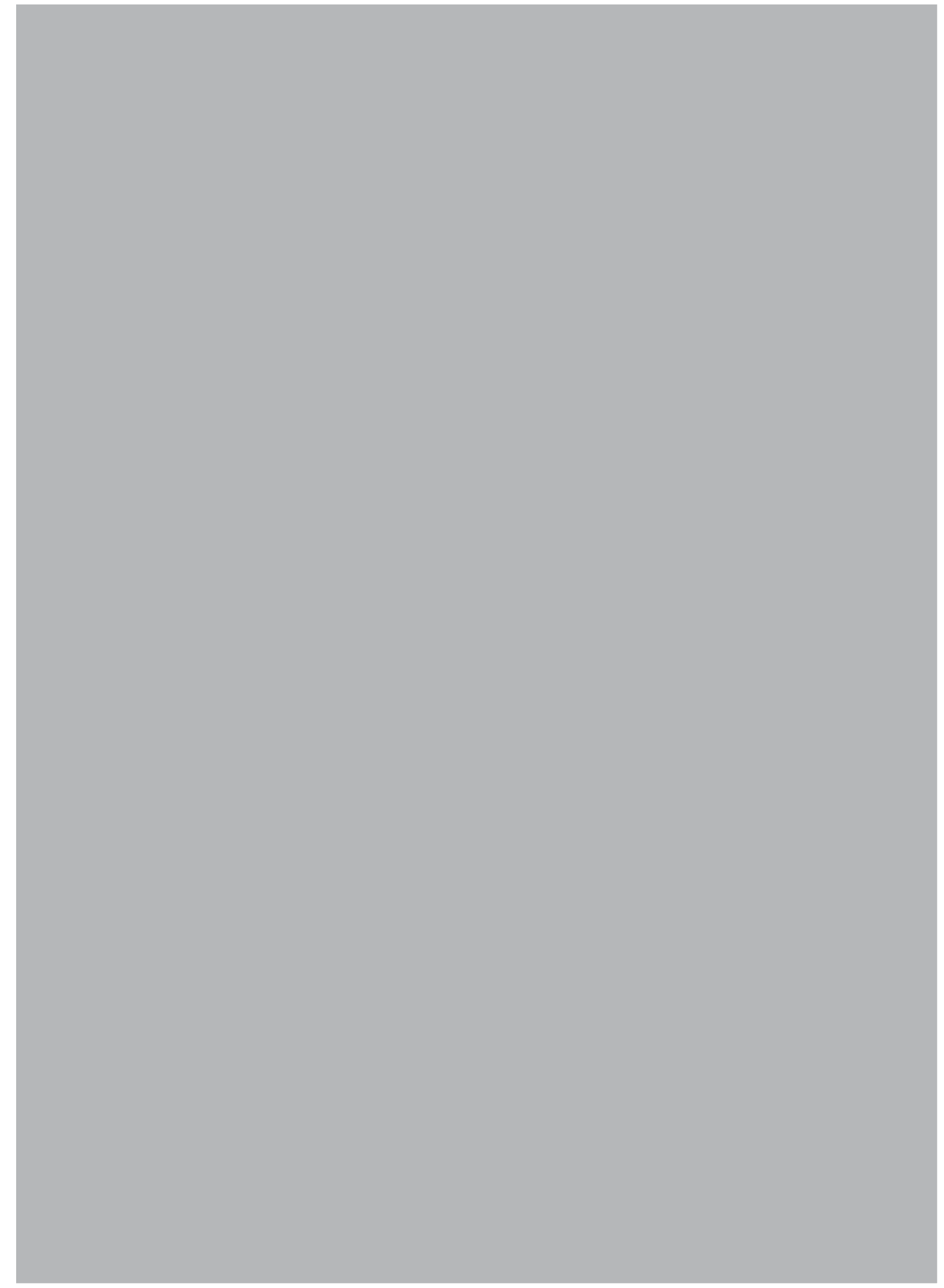




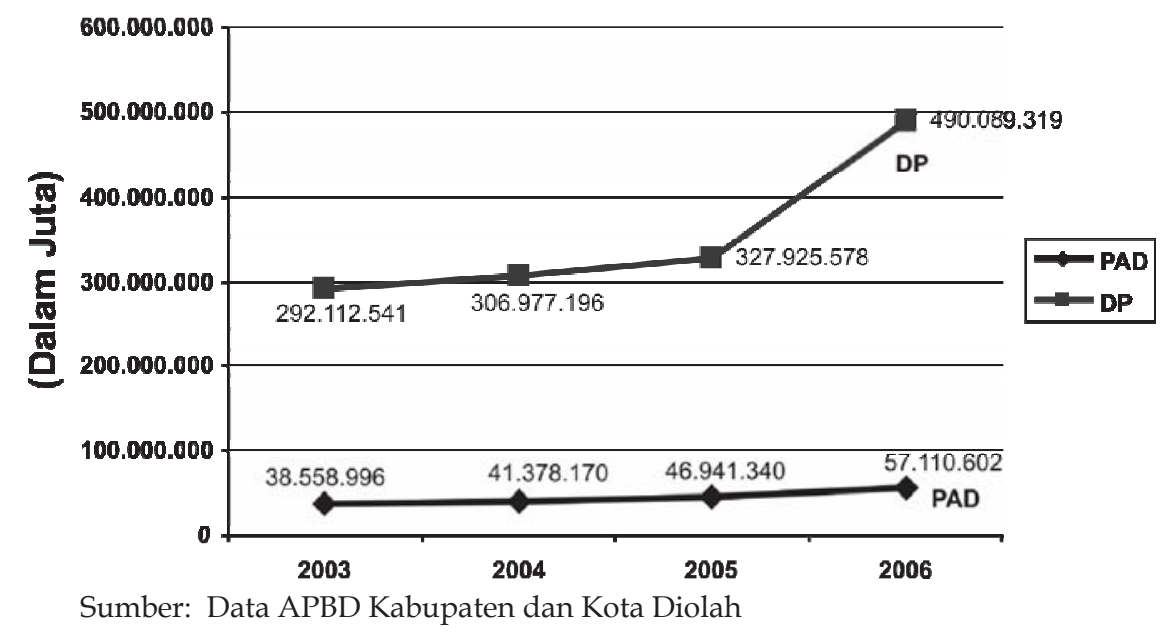

\section{Gambar 7. Perkembangan Penerimaan Pendapatan Asli Daerah (PAD) dan Dana Desentralisasi (DD) pada Kabupaten dan Kota di Provinsi Jawa Timur Tahun 2003-2006}

tidak mampu mendorong pada laju pertumbuhan ekonomi daerah, sehingga berakibat pada rendahnya pendapatan asli otonom. Beberapa daerah otonom yang memiliki koefisien ketimpangan fiskal vertikal rendah antara lain, kabupaten Blitar, kota Mojokerto, kabupaten Bojonegoro, kabupaten Situbondo, kabupaten Nganjuk, kabupaten Magetan, kabupaten Bangkalan, kota Mojokerto, serta kabupaten Jember. Sedangkan kabupaten dan kota yang memiliki koefisien ketimpangan fiskal vertikal tinggi antara lain, kota Surabaya, kota Malang, kota Kediri, kabupaten Sidoarjo, kabupaten Gresik, kabupaten Trenggalek dan kabupaten Pasuruan.

Rendahnya koefisien ketimpangan fiskal vertikal daerah otonom menunjukkan kemungkinan terjadinya inefisiensi pengelolaan APBD daerah otonom di Jawa Timur. Fenomena inefisiensi ini terlihat dari banyaknya kasus-kasus korupsi dana APBD daerah otonom, belum lagi terlambatnya pengesahan APBD oleh DPRD, serta banyak dana-dana APBD atau dana desentralisasi yang disimpan dalam bentuk SBI (Sertifikat Bank Indonesia). Bentuk-bentuk penyimpangan anggaran daerah lainnya, misalnya terjadi markup anggaran dewan daerah otonom.

Fenomena rendahnya penyerapan anggaran di Jawa Timur dapat dilihat pada instansi vertikal, dinas dan badan lingkungan di Pemerintah provinsi Jawa Timur, serta kabupaten dan kota. Besarnya sisa lebih perhitungan anggaran (SILPA) untuk tahun 2008 ini saja sebesar Rp18,2 triliun, yang meliputi; sisa APBD Jawa Timur Rp2,06 triliun, sisa APBD pada 38 kabupaten dan kota se Jawa Timur sebesar Rp10,5 triliun, serta sisa anggaran instansi vertikal, dekonsentrasi, dan tugas pembantuan di seluruh Jawa Timur sebesar Rp5,6 triliun (Jawa Pos, 28/11/2008). Menurut Asisten II Bidang Ekonomi dan Pembangunan Sekretariat Daerah Jatim Chairul Djaelani (2008) menyatakan bahwa dari Rp7,3 triliun APBD Jawa Timur tahun 2008, yang terserap baru 71 persen atau Rp5,2 triliun. Begitu pula penyerapan APBD 38 kabupaten dan kota se Jawa Timur yang besarnya Rp32,2 triliun, sampai akhir Oktober 2008 ini baru terserap Rp21,6 triliun. Penyerapan terendah terjadi di kota Surabaya dan kota Kediri sebesar 47 persen, serta kota Pasuruan 48 persen, kota Blitar 56 persen, kota Batu 54 persen, Kabupaten Banyuwangi 57 persen, Kabupaten Sampang 58 persen, dan kabupaten Trenggalek 52 persen, Rendahnya penyerapan anggaran pada kabupaten dan kota menurut Bupati Sidoarjo disebabkan karena adanya ketakutan pejabat daerah terhadap Komisi Pemberantasan Korupsi, terjadinya eskalasi harga, serta adanya keterlambatan penerbitan juklak dari pemerintah pusat.

Secara nasional sisa lebih perhitungan anggaran (SILPA) APBD kabupaten dan kota pada tahun 2007 besarnya mencapai Rp45 
sebagiannya ditransfer kembali ke daerah otonom dalam bentuk DAU, DAK dan bagi hasil pajak dan bukan pajak. Kebutuhan fiskal daerah untuk pengeluaran merupakan jumlah fiskal yang diperlukan suatu daerah untuk membiayai seluruh aktivitas pelayanan publik yang sumber biayanya berasal dari kapasitas fiskal daerah, Apabila kapasitas fiskal daerah tidak cukup untuk membiayai keseluruhan kebutuhan fiskal daerah maka terjadi kesenjangan fiskal (fiscal gap) yang selanjutnya dapat dipenuhi dari sumber eksternal yaitu pinjaman daerah maupun transfer keuangan pemerintah pusat (Ma, 1997). Kesenjangan fiskal terjadi karena tidak semua objek fiskal bisa diserahkan ke daerah karena ada objek fiskal yang bersifat distorsif sehingga tetap menjadi kewenangan pusat. Hal tersebut bisa diatasi jika pemerintah daerah mempunyai kemampuan untuk mengambil keputusan publik yang mendahulukan pelayanan publik, sehingga dapat mendorong peningkatan kapasitas fiskal. Berbagai indikator yang dapat digunakan untuk menentukan kebutuhan fiskal daerah antara lain adalah jumlah penduduk, luas wilayah, prasarana dan sarana umum, keadaan geografi, penduduk miskin, pendidikan dan kesehatan dan beberapa indikator lain yang dominan dalam wilayah daerah otonom yang bersentuhan langsung dengan pelayanan publik pemerintahan, pembangunan dan kemasyarakatan. Untuk meningkatkan kapasitas fiskal daerah, pemerintah daerah sering berfikir pragmatis, dimana setelah dana desentralisasi fiskal diperoleh, pemerintah daerah masih menggali sumber-sumber pendapatan untuk menambah kapasitas fiskal, serta memaksimisasi anggaran, sehingga konsekuensi dari hal yang demikian adalah peningkatan beban ekonomi warga masyarakat sebagai wajib pajak dan wajib retribusi. Mereka membayar dengan jumlah yang lebih besar untuk mencapai tingkat kapasitas fiskal yang diinginkan pemerintah daerah.

Peningkatan dana desentralisasi pada daerah otonom memberikan dampak pada penurunan koefisien ketimpangan fiskal vertikal. Kondisi ini merupakan bukti empiris, bahwa dana desentralisasi yang didaerahkan perlu dilakukan pengawasan, melalui peningkatan partisipasi publik yang lebih baik, sehingga dana-dana tersebut betul-betul dapat mendorong pada pengeluaran-pengeluaran yang dibutuhkan masyarakat lokal, guna mendorong peningkatan kapasitas fiskal daerah, dan tidak hanya sekedar mendorong pada pengeluaran konsumsi semata.

Dampak dana desentralisasi pengaruhnya terhadap kebutuhan pengeluaran daerah otonom telah dilakukan oleh Gamkhar dan Oates (1996), Legrenzi dan Milas (2000), serta Gorodnichenko (2001). Hasil penelitian Gamkhar dan Oates di Amerika Serikat menunjukkan bahwa pelaksanaan desentralisasi fiskal dari pemerintah Federal kepada Negara Bagian selama tahun 1953-1991 mempunyai pengaruh yang positif dan signifikan. Penelitian lain dilakukan pada pemerintah kabupaten dan kota di Italia oleh Legrenzi dan Milas (2000) yang temuannya menunjukkan bahwa pengaruh transfer keuangan pemerintah pusat terhadap total kebutuhan fiskal pada 39 kabupaten dan kota di Italia adalah positif dan signifikan.

Berdasarkan hasil penelitian yang dilakukan di Amerika Serikat dan Italia tersebut menunjukkan bahwa variabel desentralisasi fiskal berpengaruh positif dan signifikan terhadap kebutuhan untuk pengeluaran daerah. Hasil temuan tersebut sejalan dengan penelitian ini, meningkatnya dana desentralisasi telah mendorong penurunan koefisien ketimpangan fiskal vertikal. Hal ini berarti bahwa peningkatan dana desentralisasi mendorong peningkatan pengeluaran daerah yang hanya mengandalkan dana transfer dari pemerintah pusat. Perbedaan dengan penelitian ini bahwa kemampuan variabel desentralisasi fiskal dalam menjelaskan terhadap peningkatan kebutuhan pengeluaran pemerintah daerah berbeda-beda, jika di Amerika Serikat sebesar 62,0 persen, di Italia sebesar 70,0 persen dan temuan dalam studi ini sebesar 82 persen. Perbedaan yang demikian menunjukkan bahwa ketergantungan pemenuhan kebutuhan fiskal untuk pengeluaran belanja dengan mengharapkan dana desentralisasi fiskal pada daerah otonom di Indonesia masih jauh lebih tinggi dibandingkan dengan Amerika Serikat dan Italia. Ketergantungan pemenuhan kebutuhan untuk pengeluaran dari dana desentralisasi fiskal pada daerah otonom di Italia juga lebih tinggi daripada di Amerika 


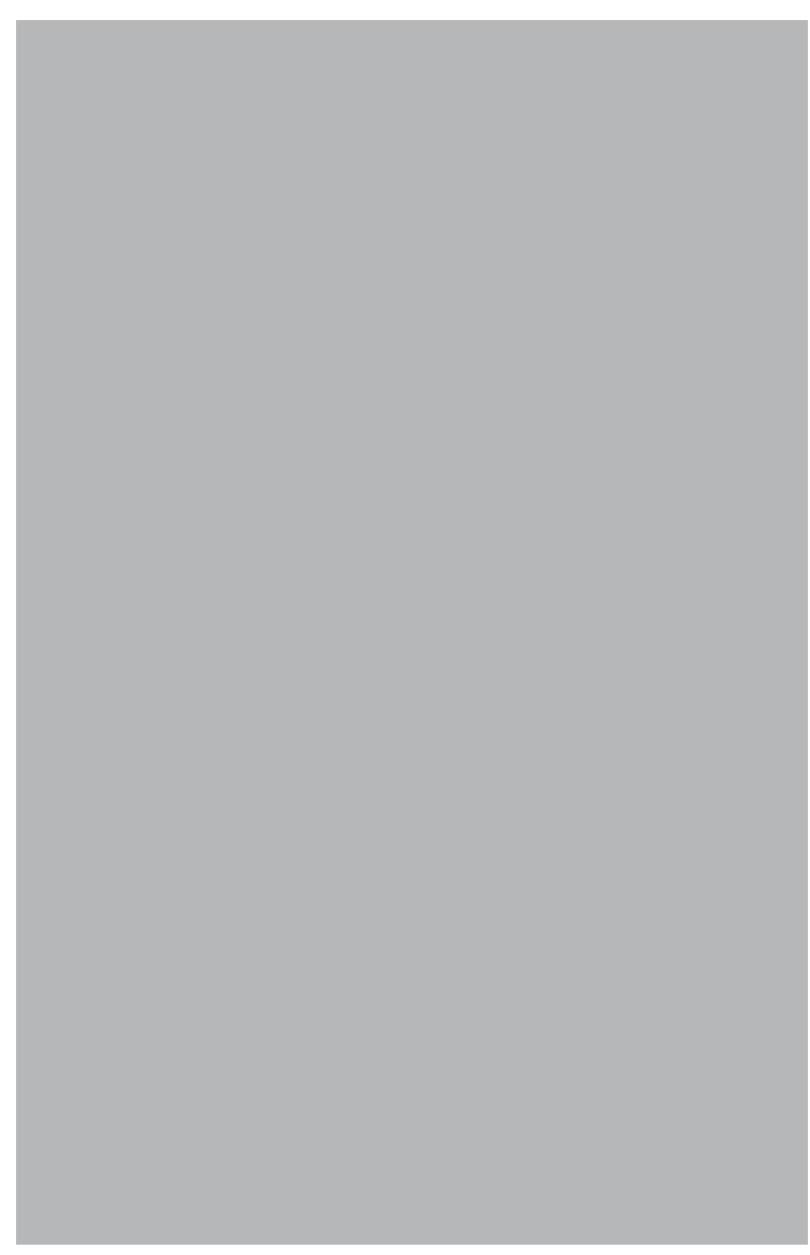

SIMPULAN

Hasil penelitian ini menemukan masukan penting sebagai upaya perbaikan kebijakan desentralisasi fiskal di masa-masa mendatang, baik bagi pemerintah kabupaten dan kota, pengelola keuangan pemerintah provinsi Jawa Timur, maupun pemerintah pusat.

Hasil penelitian ini menunjukkan bahwa kebijakan dana desentralisasi membuat daerah otonom semakin tergantung pada dana transfer dari pemerintah pusat untuk membiayai pengeluarannya. Di sisi lain, kebijakan dana desentralisasi mendorong timbulnya flypaper effect, sehingga peningkatan dana desentralisasi yang ditransfer dari pemerintah pusat telah mendorong peningkatan pengeluaran daerah otonom secara lebih besar dibandingkan peningkatan pada kapasitas fiskal daerah. Kondisi ini dapat terjadi kemungkinan adanya asymmetri information.

Peningkatan dana desentralisasi telah men- dorong pengeluaran daerah otonom menjadi semakin besar dibandingkan peningkatan pada kemampuan kapasitas fiskal daerah. Adanya keleluasaan daerah otonom dalam menyusun anggaran, serta menggunakan anggaran yang dimilikinya telah menyebabkan penurunan kemampuan kapasitas fiskal daerah, akibatnya daerah otonom kabupaten dan kota menjadi semakin tergantung pada penerimaan dari pemerintah pusat dalam bentuk dana desentralisasi. Selain itu, terjadinya penurunan koefisien ketimpangan fiskal vertikal daerah otonom pada pemerintah kabupaten dan kota ini disebabkan oleh meningkatnya tugas dan tanggung jawab yang dilimpahkan pada pemerintah kabupaten dan kota sesuai sasaran kebijakan otonomi dan desentralisasi fiskal.

Saran-saran. Adanya peningkatan dana desentralisasi dari pemerintah pusat pada daerah otonom kabupaten dan kota menunjukkan telah terdesentralisasinya sistem pemerintahan maupun perekonomian Indonesia. Berdasarkan ketentuan UU No. 32 Tahun 2004 dan UU No. 33 Tahun 2004, pemerintah daerah otonom telah memiliki keleluasan dan kewenangan mengatur dana desentralisasi yang semakin meningkat jumlahnya. Untuk itu, kepala daerah dan DPRD perlu menentukan pola belanja, program-program, serta proyekproyek prioritas yang harus didanai oleh APBD untuk mendorong pertumbuhan ekonomi daerah. Pengelolaan dana-dana desentralisasi sebagai sumber utama pembiayaan APBD perlu dilakukan lebih efisien dan efektif agar pengeluaran APBD betul-betul menyentuh pada kebutuhan masyarakat lokal sesuai preferensi yang dibutuhkan, terutama layanan dasar bidang pendidikan dan kesehatan, serta infrastruktur. Selain itu, angka-angka pengeluaran APBD hendaknya lebih menunjukkan realitas kebutuhan masyarakat lokal.

Pemerintah daerah, Bupati/Walikota bersama DPRD hendaknya dapat bekerja sama secara maksimal agar pengesahan APBD tidak molor, serta mempercepat proses pencairan APBD, sehingga dana-dana APBD dapat segera terserap untuk pelayanan publik dan pembangunan daerah. Perlu dihindari dana-dana yang disimpan dalam bentuk sertifikat Bank Indonesia (SBI). 
Pengelolaan dana APBD hendaknya dapat dilakukan secara efektif dan efisien, sehingga pemerintah daerah dan DPRD bisa koordinasi dan konsultasi dengan pihak penegak hukum untuk mewujudkan terciptanya pemerintahan yang bersih (good governance), sehingga di akhir tahun anggaran mereka tidak terjerat oleh kasus hukum karena korupsi. Selain itu, meningkatnya dana desentralisasi dipergunakan sebaik-baiknya untuk belanja daerah, maka perencanaan program maupun proyek-proyek daerah perlu terus diperbaiki, termasuk upayaupaya peningkatan kualitas aparat pemerintah daerah dalam menangani berbagai proyek yang didanai pemerintah, baik pusat maupun daerah.

\section{DAFTAR PUSTAKA}

Bird M, Richard and Vaillancourt. 2000. Desentralisasi Fiskal di Negara-negara Berkembang. Jakarta: PT. Gramedia Pustaka Utama.

Bird, R. 2003. Asymmetric Fiscal Decentralization: Glue or Solvent?. International Studies Programme. Georgia State University. Working Paper.

Bird, Richaerd and Litvack, Jennie, Ahmad. 1998. Decentralization in Developing Country. Washington. DC: The Word Bank.

Bird, Richard and Tarasov, Andrey V. 2002 Closing the Gap: Fiscal Imbalances and Intergovernmental Transfer in Developed Federations. International Studies Program. Working Paper 02-02. March 2002. Andrew Young. School of Policy Studies. Gergia State University.

Bird, Richard M, dan Michael Smart. 2001. Intergovernmental Fiscal Transfer: Some Lesson from International Experience dalam makalah yang disampaikan dalam symposium on Intergovernmental Transfers in Asian Countries: Issues and Practices. Tokyo.

Boadway and Wildasin, F.D. 2005. Decentralized Antipoverty Program Delivery in
Developing Countries. Journal of Public Economics Vol. 89. pp. 675-704.

Boadway and Wildasin. F.D. 1984. Public Sector Economics. Second Edition. Boston: Little Brown and Company.

Boadway and Wildasin. F.D. 2003. Political Economy of Land Reforms in West Bengal 1978-98. Working paper. Institut for Economic Development. Boston University.

Boex, Jamie, Robert McNab and Mary Beth Walker, 2001. The analysis of Fiscal Decentralization Policies: A Review of Statistics and Regression Techniques. Fiscal Policy Training Program. Fiscal Decentralization in Developing and Transition Economies. Georgia USA: World Bank Institute and Georgia State University.

Boex, Jamie. 2001. An Introductory Overview of Intergovermental Fiscal Relations. International Studies Program. Andre Young School of Policy Studies. Atlanta: Georgia State University.

Boex, Jamie. 2001. An Introductory Overview of Intergovermental Fiscal Relations. International Studies Program. Andre Young School of Policy Studies. Atlanta: Georgia State University.

Browning, E.K and Browning, J.M. 1979. Public Finance and the Price System. New York: McMillan Publishing Co. Inc.

Campo, Salvatore S. and Sundaram, P. 2002. To serve and to preserve: Improving Public Administration in A Competitive world. Sean Development Bank.

Davey. Kenneth. 1989. Hubungan Keuangan Pusat-Daerah di Indonesia dalam Keuangan Pemerintah Daerah di Indonesia. Jakarta: UI Press.

Degefa, Derrese. 2003. Fiscal Decentralization in Africa: A Review of Ethiopia's Experience. Economic Commission for Africa. Ad-Hoc Expert Group Meeting. Addis Ababa: UNCC.

Departemen Keuangan. 2004. Rancangan Anggaran pendapatan dan Belanja Negara Tahun 
Anggaran 2004. Jakarta.

Devas, Nick, Binder B, Booth, A, Davey, Kelly. R. 1988. Keuangan Pemerintah Daerah di Indonesia. Jakarta: UI press.

Fischer, Stanley. 1993. The Role of Macroeconomic Factors in Growth Journal of Monetary Economics 32: 485-512.

Fisher, Ronald C. 1996. State And Local Public Finance. Departement of Economics. Michigan State University. Chicago. United State: IRWIN.

Fjeldstad, Odd-Helge. 2001. Intergovernmental Fiscal Relations in Developing Countries: A review of issues. CMI Working paper. No. 11. Chr. Bergen. Norway: Michelsen Institute.

Gamkhar, S. \& Wallace Oates. 1996. Asymetries in the Response to Increases and Decreases in Intergovernmental Hibahs: Some Empirical Findings. National Tax Journal. Vol 49 No. 4 (December 1996) pp. $501-12$.

Gemmell, N., Oliver Morrissey and Abuzer Pinar. 1998. Fiscal Illusion and the Demand for Local Government Expenditure in England and Wales. School of Economics. Discussion Paper 98/19.

Gorodnichenko, Y. 2001. Effects of Intergovernmental Aid on Fiscal Behavior of Local Governments: The Case of Ukraine. A Thesis Submited in Partial Fulfillments of the Requirements for the Degree of Master of Arts in Economics. Economics Education and Research Consortium. The National University of "Kiyv-Mohyla Academy. Not Published.

Hamid, Edi Suandi. 2003. Ketimpangan Fiskal Vertikal dan Formula Alternatif Dana Alokasi Umum (DAU). Disertasi UGM (tidak dipublikasikan). Yogyakarta.

Hamid, Edi Suandi. 2005. Formula Alternatif Dana Alokasi Umum (DAU) Upaya Mengatasi Ketimpangan Fiskal dalam Era Otonomi Daerah. Jogjakarta: UII Press.

Hines, J. R., Jr and Richard H. Thaler. 1995.
Anomalies The Flypaper Effect. Journal of Economic Perspectives - Volume 9. Number 4-Fall 1995 - pages 217 - 226.

Langoday, O. T. 2006. Pengaruh Desentralisasi dan pemerataan Fiskal terhadap Kapasitas dan Kebutuhan Fiskal serta Pajak Daerah di Provinsi Nusa Tnggara Timur. Disertasi Universitas Brawijaya (Tidak dipublikasikan).

Legrenzi, Gabriella and Costas Milas. 2002. Non Linear and Asymmetric Adjustment in the Local Revenue-Expenditure Models: Some Evidence from the Italian Municipalities. Journal of Economic Literature (JEL) Classification Number: H10. H71. C22.

Lewis, B.D. 2001. The New Indonesian Equalisation Transfer. Bulletin of Indonesian Economic Studies. Vol 37 No. 3 (December 2001).

Lewis, Blane D. dan J, Chakeri. 2004. Central Government Spending in the Regions Post-Decentralisation. Bulletin of Indonesian Economic Studies 40 (3): 379-394.

Litvack, Jennie. Ahmad. Jundid. and Bird. Richard. 1998. Decentralization in Developing Country. Washington DC.: The Word Bank.

Ma, Jun. 1997. Intergovernmental Fiscal Transfer: A Comparison of Nine Countries (Cases of the United States. Canada. The United Kingdom. Australia. Germany. Japan. Korea. India and Indonesia). Paper prepared for Macroeconomic Management and Policy Division. Economic Development Institut. The World Bank.

Mardiasmo. 2001. Manajemen Penerimaan Daerah dan Struktur APBD dalam Era Otonomi Daerah. Makalah workshop Kerjasama SIAGA Project dan STIE Kerjasama Yogyakarta.

Mardiasmo. 2002a. Otonomi dan Manajemen Keuangan Daerah. Yogyakarta: Andi.

Mardiasmo. 2002b. Akuntansi Sektor Publik. Yogyakarta: Andi.

Martinez Vasquez, J. and R. McNab. 2005. Fiscal 
Decentralization, Macrostability, and Growth. International Studies Programme. Georgia State University. Working Paper 0506.

Martinez, Vazques Jorge 2005. Fiscal Decentralization, Macrostability, and Growth.

Martinez, Vazques Jorge. and Robert M. Mc Nab. 2001. Fiscal Decentralization and Economic Growth. International Studies Program. Working Paper \#01-1 January 2001. Andre Young School of Policy Studies. Georgia State University. Atalanta.

Martinez-Vasquez, J., and R. McNab. 1997. Fiscal Decentralization. Economic Growth. and Democratic Governance. International Studies Programme. Georgia State University. Working Paper.

Martinez-Vasquez. J. and Jameson Boex. 2001. Russia's Transition to a New Federalism. Report No. 22026. World Bank Institute. Learning Resource Series. Washington. DC.

Martinez-Vasquez. J. and R. McNab. 2001. Fiscal Decentralization and Economic Growth. International Studies Programme. Georgia State University. Working Paper \# 01-1

Oates, Wallace. E. 1972. Fiscal Federalism. New York: Harcourt Brace Jovanovich.

Oates, Wallace. E. 1999. An Essay on Fiscal Federalism. Journal of economic literature. 37 (3). 1120-1149.

Oates, Warren E. 1993. Fiscal Decentralization and Economic Development. National Tax Journal 46. (2): 237-243.

Penyelenggaraan Dekonsentrasi. (PP No. 39 Th. 2001). Dilengkapi dengan PP No. 52 Th. 2001 tentang Penyelenggaraan Tugas Pembantuan. PP No. 105 Th. 2000 Tentang Pengelolaan dan Pertanggungjawaban Keuangan Daerah. PP No. 106 Th. 2000 tentang Pengelolaan dan Pertanggungjawaban dalam Melaksanakan Dekonsentrasi dan Tugas pembantuan.

Peraturan Pemerintah Nomor 104 Tahun 2000 Tentang Dana Perimbangan. Jakarta:
Sekretariat Negara Republik Indonesia.

Peraturan Pemerintah Nomor 106 Tahun 2000 tentang Pengelolaan dan Pertanggungjawaban Keuangan dalam Pelaksanaan Dekonsentrasi dan Tugas Pembantuan. Jakarta: Sekretariat Negara Republik Indonesia.

Peraturan Pemerintah Nomor 107 Tahun 2000 Tentang Pinjaman Daerah. Jakarta: Sekretariat Negara Republik Indonesia.

Prud'homme, Remy. 2001. Fiscal Decentralization and Intergovernmental Fiscal Relation. A Summary Report Prepared for the UNCDF Symposium Decentralization Local Governance in Africa.

Prud'homme. Remy. 1995. The Dangers of Decentralisation. The World Bank Research Observer 10. 201-2015

Pusat Antar Universitas (PAU) UGM. 2000. Laporan Akhir Kajian Profil Daerah Tingkat II Ditinjau dari Aspek Potensi Penerimaan Daerah Kerjasama

Ramirez, A. G. Ranis. dan F. Stewart. 1998. Economic Growth and Human Capital. QEH Working Paper No. 18.

Ramirez. A.. Ranis. G dan Stewart. F.. 1998. Economic Growth and Human Development. Working Paper Number 18. UNDP. Yale University. Queen Elizabeth House.

Rao, M. Govinda. 2001. Poverty Alleviation under Fiscal Decentralization. Fiscal Policy Training Program 2001. Fiscal Decentralization Course. July 23-August 3. 2001. Atlanta. Georgia: World Bank Institute and Georgia State University. Andrew Young School of Policy Studies.

Rappaport. J. 1999. Local Growth Empirics. CID Working Papers No. 23. Juli 1999.

Reinikka, R dan Svensson. 2004. Local capture: Evidence from a Central Government Transfer program in Uganda. Quarterly Journal of Economics. 119. 679-705.

Rezk, Ernesto. 1998. Argentina: Fiscal Federalism and Decentralization dalam Bird. Ricard M dan Francois Vaillancourt (eds) Fiscal 
Decentralization in developing Countries. Cambridge University Press.

Rodden, J. 2002. The Dilemma of Fiscal Federalism: Hibahs and Fiscal Performance Arround the World. American Journal of Political Science. 46 (3): 670-687.

Rodden. J. Eskeland. G.S dan Litvack. J.. 2003. Fiscal Decentralization and the Challenge of Hard Budget Constraints. Cambridge and London: MIT Press.

Roemer. J. E.. and Joaqium Silvestre. 2000. The Flypaper Effect is not an Anomaly. Journal of Economic Literature. Classification Number: D72. H41. H71. H77. March 2000.

Rondinelli,. D. 2001. Concept of Fiscal Decentralization and Worldwide Overview. Topic I. Intergovernmental Fiscal Relation \& Local Financial Management Program. World Bank Institute.

Rosen, H. S. 2002. Public Finance. New York: McGraw-Hill. Irwin.

Shah. Anwar and John Whalley. 1991. Tax Incidence Analysis of Developing Countries: An Alternative View. The World Bank Economic Review 5 (3): 535-52.

Shah. Anwar dan Zia Qureshi. 1994. Intergovernmental Fiscal Relations in Indonesia. World Bank Discussion paper No. 239. Washington DC.: The World Bank.

Shah. Anwar. 1994. The Reform of Intergovernmental Fiscal Relation in Developing and Emerging Market Economics. Policy and Research Series No. 23. Washington DC: The World Bank.

Sidik. M. 2003. Dana Alokasi Umum. Konsep. Hambatan dan Prospek di Era Otonomi Daerah. Editor. Jakarta: Penerbit Kompas.

Sidik. M. 2002. Format Hubungan Keuangan Pemerintah Pusat dan Daerah yang Mengacu pada Pencapaian Tujuan Nasional. Paper disampaikan pada Seminar Nasional
Public Sector Scorecard. Jakarta 17-18 April 2002. Jakarta.

Sidik. M. 2002. Perimbangan Keuangan Pusat dan Daerah Sebagai Pelaksanaan Desentralisasi Fiskal (antara teori dan aplikasinya di Indonesia). Makalah seminar Nasional yang diselenggarakan oleh Program S2 Politik Lokal dan Otonomi Daerah Universitas Gadjah Mada Yogyakarta.

Sidik. M. and Kadjatmiko. 2003. Indonesia's Fiscal Decentralization: Combining Expenditure Assignment and Revenue Assignment. Ministry of Finance Republic of Indonesia. Not Published.

Smoke. Paul. 2001. Fiscal Decentralization in Developing Countries. A Review of Current Concepts and Practice. Democracy. Governance and Human Rights Programme Paper Number 2 February 2001. United Nations Research Institute for Social Development.

Undang-Undang Nomor 22 Tahun 1999. Tentang Pemerintahan Daerah. Sekretariat Negara Republik Indonesia. Jakarta (Direvisi menjadi UU No. 32/2004).

Undang-Undang Nomor 25 Tahun 1999. Tentang Perimbangan Keuangan Pemerintah Pusat dan Daerah. Sekretariat Negara Republik Indonesia. Jakarta (Direvisi menjadi UU No. 33/2004).

World Bank. 1996. Indonesia: Dimensions of Growth. Washington DC.: World Bank.

World Bank. 2000a. World Development Report 1999/2000: Entering the 21 ${ }^{\text {st }}$ Century. Washington. DC.: World Bank.

World Bank. 2001. World Development report: Attacking poverty 2000/2001. Washington DC: World Bank.

World Bank. 2004. World development report 2004: Making Services Work for Poor People. Washington D.C: World Bank. 